\title{
COMMENTARY
}

\section{Institutional Economics-The Economics of Ecological Economics!}

\author{
Arild Vatn *
}

On its homepage, The International Society for Ecological Economics states that 'ecological economics exists because a hundred years of disciplinary specialization in scientific inquiry has left us unable to understand or to manage the interactions between the human and environmental components of our world.' Understanding and managing these interactions well depend not only on a sincere focus on the interactions, as important is how we understand the dynamics of the economic, social, and environmental subsystems of our world. We know that the whole is more than the sum of its parts, but it is important also that the way we understand the parts captures the specificities of each subsystem. Therefore, ecological economics should not be 'agnostic' about what kind of economic theory forms its basis. Many ecological economists adhere to the neoclassical brand of economics - at least if we look at papers presented in our journal (Ecological Economics) and at conferences hosted by the society (The International Society for Ecological Economics). But I think, given its focus, neoclassical economics is not suitable as a basis for ecological economics. While I observe several alternatives that may offer progress, I will in this short paper show what institutional economics, as an alternative, can offer ecological economics.

Ecological economics has a normative basis, in the sense that it looks for ways to move the world onto a sustainable development path. Humans live in a biophysical environment, characterized by interdependencies, limits, and thresholds, and so we need an economic theory that is well suited to

\footnotetext{
* Faculty of Landscape and Society, Department of International Environment and Development Studies, Norwegian University of Life Sciences, Universitetstunet 1, 1432 Ås, Norway, arild.vatn@nmbu.no

Copyright (C) Vatn 2018. Released under Creative Commons Attribution-NonCommercial 4.0 International licence (CC BY-NC 4.0) by the author.

Published by Indian Society for Ecological Economics (INSEE), c/o Institute of Economic Growth, University Enclave, North Campus, Delhi 110007.
}

ISSN: 2581-6152 (print); 2581-6101 (web).

DOI: https://doi.org/10.37773/ees.v1i1.4 
study human action in such a context and describes well the complexities of human motivation. In these regards, neoclassical economics fails for several reasons. Here, I emphasize three.

First, it builds its analyses on 'solved political problems' (Lerner 1972)—for example, given distribution of (property) rights-while sustainability issues are typically unresolved political problems, as new limits and thresholds are continuously approached.

Second, it holds that human action is based on the pursuit of maximizing individual utility, a perspective that is both empirically flawed and unable to handle interdependencies well. I note that there are developments within the branch of behavioural economics that offer progress regarding the understanding of human action, while a methodological individualist ontology is maintained.

This leads to the third point: The individual is seen as autonomous, which implies that social processes have no influence on what the individual prefers. In short, it offers a very limited basis for studying collective action.

Institutional economics can largely be divided into two main schools'new' and 'classic'. New institutional economists deviate from neoclassical economics mainly by including information and transaction costs (Coase 1960, 1984; Eggertsson 1990; North 1990, 2005; Williamson 1985, 2000). This challenges the assumption that human action is based on the pursuit of maximizing individual utility. Williamson (1985) therefore distances himself by accepting bounded rationality and emphasizing opportunism. The 'old North' takes a similar position (North 2005), while he continues to emphasize that individuals are autonomous.

Classical institutional economics has its origin in the works of authors like Veblen $(1898,1919)$ and Commons $(1931,1934)$. Its revival in the 1980sfor example, in the work of Hodgson (1988) and Bromley (1989)—was at least in part a reaction to the development of new institutional economics. Classical institutional economics emphasizes the role of culture and social processes and sees humans as socially constructed, and in this way it goes beyond new institutional economics. This implies that our perceptions, values, and preferences depend on which societies and cultures we belong to. Here, institutions - understood as conventions, norms, and formal rules-play a crucial role (Scott 2014; Vatn 2005): they protect the values a society prioritizes and outline appropriate actions. Through changing institutions, we can facilitate not only new constraints for the 'egocentric individual', but also create new meaning for ourselves and support various forms of collective and responsible actions. 
Classical institutional economics emphasizes that people are interdependent, as they act within common environments. Traditionally, its proponents have focused mainly on cultural and political interdependencies. Introducing classical institutional economics to ecological economics implies expanding its focus to include also physical interdependence, which implies that there will be both conflict and the need for coordination. Classical institutional economics emphasizes that the role of institutions is to define whose interests should be protected and how easy or demanding it will be to coordinate actions that are interdependent.

Given the above, I comment briefly on the following four aspects of classical institutional economics as applied to ecological economics (see also Vatn 2015):

1) The role of property rights. These rights specify who gets access to which resources and, so, define whose interests are protected. Therefore, property rights are key institutional structures in a society defining whose interests get protection through specifying who gets access to which resources.

This is a political question and raises several issues regarding the normative basis of a society, for example, its understanding of justice and treatment of cost-shifting behaviour (Kapp 1971; Martinez-Alier 2002). Moreover, as property rights ensure access to resources over time, they are key to sustainable development. Equally important is the way interactions between resource-holders and -users are institutionalized-for example, as trade, command, or cooperation. Rights to resources and interaction rules (like trade, command and cooperation) form resource regimes. Classical institutional economics emphasizes how such regimes influence distribution as well as shape human action by influencing the costs of interaction (transaction costs), people's perceptions, and motivation structures.

2) The role of transaction costs. Costs of interaction (transaction costs) depend on the kind of institutional structures established. Environmental degradation is the result of myriads of independent actions made by individuals, households and firms. To establish sustainability demands institutions that facilitate coordination, that makes coordination affordable and meaningful for people when acting. The kind of resource regimes established influences these costs heavily.

3) The effects on perceptions. Classical institutional economics also emphasizes that how and what we perceive, depends on how and what we have learned to 'see'; how we have been trained to interpret information determines how we perceive a problem and even what we 
perceive as a problem. Including this aspect is crucial for a theory that aims at supporting sustainable development.

4) The effect on motivation. Last, but not least, classical institutional economics understands rationality and motivation as plural concepts. It is based on the observation that humans are able to act in ways that are socially responsible - that are 'better for the group' or for others - and not only in ways that are purely self-regarding. Institutions are important in that they can make clear when social rationality, as opposed to individual rationality, is expected, and thus may support different types of rationality. This is a crucial insight, and it offers the hope that a sustainable future is possible. Whereas neoclassical economics demands a physical world without serious limits-that is, it emphasizes selfinterest and economic expansion-classical institutional economics acknowledges that there are limits and is based on the perspective that we through institutional change can facilitate the level of cooperation necessary to abide by such limits.

While insights regarding the relationship between institutions and human motivation offer hope that sustainability is possible, much work is needed to develop the institutions that could foster such a development. We have certain insights regarding the management of local 'commons' (for example, Ostrom $(1990,2005)$. However, when it comes to how we should organize production and trade more generally, we are only scratching the surface regarding what sustainability demands as well as what 'works in practice'. I hold that (classical) institutional economics offers a good basis for that endeavour; and my plea to ecological economists is that we should work much more seriously on these fundamental issues of economic organization.

\section{REFERENCES}

Bromley, D. W. 1989. Economic Interests and Institutions. The Conceptual Foundations of Public Policy. Oxford: Basil Blackwell.

Coase, R. H. 1960. “The Problem of Social Cost.” Journal of Law \& Economics 3: 144. doi:10.1086/466560. https://doi.org/10.1086/466560

Coase, R.H. 1984. "The New Institutional Economics." Journal of Theoretical and Institutional Economics, 140 (1): 229-231.

Commons, J.R. 1931. "Institutional Economics.” American Economic Review, 21: 648657.

Commons, J.R. [1934] 1990. Institutional Economics. Its place in Political Economics. New Brunswick, Transaction Publishers. 
Eggertsson, T. 1990. Economic Behaviour and Institutions. Cambridge: Cambridge University Press. https://doi.org/10.1017/CBO9780511609404

Hodgson, G. M. 1988. Economics and Institutions A Manifesto for a Modern Institutional Economics. Cambridge Polity Press. https://doi.org/10.9783/9781512816952

Kapp, K. W. 1971. The Social Costs of Private Enterprise. New York: Schoken Books. Lerner, A. 1972. "The Economics and Politics of Consumer Sovereignty." American Economic Review 62 (2): 258-66.

Martinez-Alier, J. 2002. The Environmentalism of the Poor. Cheltenham: Edward Elgar. https://doi.org/10.4337/9781843765486

North, D. C. 1990. Institutions, Institutional Change and Economic Performance. Cambridge: Cambridge University Press. https://doi.org/10.1017/CBO9780511808678.

North, D. C. 2005. Understanding the Process of Economic Change. Princeton, NJ:

Princeton University Press. https://doi.org/10.1515/9781400829484.

Ostrom, E. 1990. Governing the Commons: The Evolution for Collective Action.

Cambridge: Cambridge University Press.

https://doi.org/10.1017/CBO9780511807763

Ostrom, E. 2005. Understanding Institutional Diversity. Princeton, NJ: Princeton University Press.

Scott, W. R. 2014. Institutions and Organizations: Ideas, Interests and Identities. 4th ed. Los Angeles: Sage Publications.

Vatn, A. 2005. Institutions and the Environment. Cheltenham: Edward Elgar.

Vatn, A. 2015. Environmental Governance. Institutions, Policies and Actions. Cheltenham: Edward Elgar.

Veblen, T., 1898. "Why is Economics not an Evolutionary Science." Quarterly Journal of Economics, 12: 373-397. https://doi.org/10.2307/1882952

Veblen, T. 1919. The Place of Science in Modern Civilisation and Other Essays. New York: Huebsch.

Williamson, O. E. 1985. The Economic Institutions of Capitalism. New York: Free Press. Williamson, O.E. 2000. “The New Institutional Economics: Taking Stock/Looking Ahead." Journal of Economic Literature, XXXVIII (3): 595-613. https://doi.org/10.1257/jel.38.3.595 